\title{
Determining the contribution of corporate social responsibility on organizational performance
}

\author{
Ijeoma, N. B. ${ }^{1,}$, Oghoghomeh, T. $^{2}$ \\ ${ }^{1}$ Deptartment of Accountancy, Nnamdi Azikiwe University, Awka-Nigeria \\ ${ }^{2}$ Department of Accountancy, Delta State University, Asaba Campus-Nigeria
}

\section{Email address:}

amaro4baya@yahoo.com (Ijeoma, N. B.)

\section{To cite this article:}

Ijeoma, N. B., Oghoghomeh, T.. Determining the Contribution of Corporate Social Responsibility on Organizational Performance. International Journal of Economics, Finance and Management Sciences. Vol. 2, No. 1, 2014, pp. 84-91.

doi: $10.11648 /$ j.ijefm.20140201.19

\begin{abstract}
This study was on determining the contribution of corporate social responsibility on organizational performance. The purpose of this study was to determine the contribution of corporate social responsibility on company's profit after tax and to ascertain if there exists significant contribution of corporate social responsibility on company's profit after tax. The source of data for this study was secondary data obtained from Central Bank of Nigeria Statistical Bulletin 2010 and annual reports 2008-2012 of three selected public limited companies operating in Nigeria. The statistical tool employed was the regression analysis and the line graph analysis. From the result of the analysis it was found that corporate social responsibility was able to explain and contribute significantly to company's performance more in OANDO Group Nig. Plc since it was able to explain about $96.1 \%$ of the behavior of profit after tax in OANDO Group Nig. Plc, $21.4 \%$ in Guiness Nig. Plc and $9.5 \%$ in Total Nig. Plc. This result implies that OANDO Group Nig. Plc was observed to spend more in terms of corporate social responsibility amongst the observed company's and in turn corporate social responsibility contributing to its performance. Also, it was found that Guniess Nig. Plc recorded the largest profit after tax over the observed period followed by OANDO Group Nig. Plc. It can be generalized that sustainability reports does have an association with company performance. Social performance disclosure has an association with company's performance as was found by the result of OANDO Group Nig. Plc. For companies, improving sustainability performance is important and it is equally important as improving company's financial performance. Sustainability means the development that meets the needs of the present without compromising the ability of future generations to meet their own needs. It means that, in running the business, a company need to concern to the needs of future generations. Though reporting on its environmental performance may expose a company to criticisms and also have minimal effect in the short run. It is advisable that the company continues to disclose its environmental performance because in the long run it would help in achieving sustainability.
\end{abstract}

Keywords: Corporate Social Responsibility, Sustainability, Environmental Performance, Regression Analysis, Report

\section{Introduction}

It has been observed recently, that companies have been called upon to fulfill the needs of wide range of stakeholders who pay attention to company's value. They are interested in understanding the approach and performance of a company in managing the sustainability such as economic, environmental, and social aspects, including the potential for value created from managing sustainability. Besides providing financial information for shareholders, a company needs to publish nonfinancial information as well [1]. Sustainability reporting is a new term which is widely used to explain the communication of the companies' effect on social, environmental and economic performance. Sustainability reports are also referred to as "triple bottom line reports" (profits, people, and planet). Many large companies publish such kind of reports especially for the company which is socially environmentally sensitive such as oil and gas, mining, chemical, automotive, computers, and electronics [2]. Triple bottom line is a catch phrase that is increasingly being used as a heuristic to help conceptualize sustainability as well as provide a framework for reporting against sustainability parameters [3].

Triple bottom line reporting is the corporate communication with stakeholders that describes the company approach to managing economic, environmental 
and social dimension of its activities. Triple bottom line report is usually a stand-alone annual report through which an organization accounts for its impacts on the broader environment, society and economy, as an advance on a traditional annual report which focuses solely on an organization's financial accountability. [4], stated that the purpose of sustainability reporting is to provide information which holistically assesses organizational performance in a multi-stakeholder environment. In the social area, it is focused on contributing back to the society and community, providing growth and development opportunities for employees and improving relationships and practices for customers, suppliers, governments and communities. The notion of reporting against the three components (or bottom lines) of economic, environmental, and social performance is directly tied to the concept and goal of sustainable development. According to [5], the implementation of a triple bottom line approach is premised on a strategic approach to economic, environmental and social considerations; the definition of values associated with economic, environmental and social matters; and identifying and measuring performance areas of importance to key stakeholders. [6], defined triple bottom line reporting as the measurement, management and reporting of economic, environmental and social performance indications in a single report. They added that triple bottom line reporting is therefore best seen as a process that includes managing, measuring and publicly reporting multi-dimensional performance and integrating it with management process. It goes beyond the traditional way of reporting mechanism and encourages businesses to give closer attention to the whole impact of their commercial activities over and above their financial performance [7]. Such reporting tool responds to all stakeholders demands that company take part in, be accountable to substantiate their membership in society. In addition, [2], explained that sustainability reporting is closely related with corporate social responsibility reporting. It has a voluntary character. Social responsibility reporting refers to the measurement and communication of information about company's effect on employee welfare, the local community, and the environment. Information on company welfare may involve working conditions, job security, equal opportunity, workforce diversity, and child labor. Environmental issues may include the impact of production process, products, and services on air, water, land, biodiversity, and human health. Social responsibility reporting is the communication about a company's responsibility for social and environmental aspects surrounding the business. This reflects that companies owe stakeholders an annual accounting of their social and environmental performance as the financial information they provide to shareholders. [8], explained that Corporate Social Responsibility is an important issue in contemporary international debates. Central to Corporate Social Responsibility is a concern for sustainability, particularly for environmental sustainability, as this is crucial for long-term success and survival even in the financial terms by which firms normally judge their success. Indeed many corporate reports, which used to be designated as environmental reports and subsequently as Corporate Social Responsibility reports have now been repackage as sustainability reports. Corporate social responsibility is a concept whereby companies integrate social and environmental concerns in their business operations and in their operations within their stakeholders on a voluntary basis. [9], reported that many articles stated that sustainability has a capacity for long-term financial performance, investment return, and also value creation which refers to achieving sufficient profits. Companies that are apathetic to their environmental responsibility might experience eventual crashes on their stock price if their investors are rational in considering the future value of the firm based on its present state of environmental responsibility. The most vital challenges confronting the public limited companies while adopting the triple bottom line approaches as their corporate philosophy has been the difficulty in stating the key issues to be in their triple bottom line report because it hasn't been stated as a statue in any acts guiding corporations in Nigeria. Also, the use of triple bottom line reporting has raised doubts as to the effect it has on the financial performance of companies or if companies are just diverting their time and resources to an unworthy task that would have no effect on its society, in the nearest future. However, it has been an argument with concern in Nigeria that during the production of a commodity, the company releases gas emissions and waste to the environment which might be harmful to the individuals in the area. Such actions will lead consumers and investors likewise to develop a negative attitude towards the company's product and investing in it respectively. Such cases in Nigeria include the Niger Delta oil spillage which has encouraged kidnapping of both foreign and local workers of most oil firms operating in the region. The purpose of this study was to determine the contribution of corporate social responsibility on company's profit after tax and to ascertain if there exists significant contribution of corporate social responsibility on company's profit after tax. [10], noted that corporate social responsibility emerged in the 1980's as a label for a philosophy of economic growth in business that values only those gains that can endure into future generations.

\subsection{Literature Review}

[11], explained that the perspective of sustainability provides a framework to create value which refers to both achieving sufficient profits and to satisfying the request of a diverse group of stakeholder. There is also a perception that organizations are producing sustainability reports primarily as a public relations exercise to give impression of concern over social and environmental issues. [12], noted that there is a growing recognition among investment analyst that numerous business drivers upstream of a company's profit and loss statement, including environmental, social, and governance, contribute to long-term financial performance and investment returns. [9], proved in their study that firms 
which invest in social and environmental would have higher return on total assets (ROTA) compare to firms that do not invest. The variable of sustainability practices is measured with employee health and safety (EHS), Waste Management (WM), and Community Development (CD). [13], stated that beside the increasing of global environmental awareness and the campaign of sustainable development, the increasing trend of sustainability reporting is also supported by the increasing number of guidelines provided by various government organizations and industry bodies. In his contribution, [14] attempted to find a possible relationship between corporate social responsibility disclosure and firm's financial performance in his study. The results of his study showed that economic and environmental performance disclosures have significant positive relationship with financial performance (measured by ROA), while social performance disclosures do not show significant relationship. According to research conducted by [15], with a data set of 3,237 Japanese firms observed that in the short term, environmental investment does not affect firm performance significantly, whereas in the long term environmental investment increases firm performance significantly. [16], point to the interaction of four forces that make corporate responsibility a mainstream business issue. He noted them as;

1. The development of technology and communications which result in companies having no place to hide.

2. The increased prominence of multinationals globally and the growth in the value and visibility of their brands which make them more susceptible to scrutiny.

3. Demographic change and development which encompasses issues such as an ageing population in the developed world, limited access to health.

4. The revolution of values and the decline in deference for institutions.

[17], in their study examined triple bottom line paradigm by emphasizing and integrating three key dimensions of sustainable developments, which includes; profit, Planet and People, forced corporations to widen their circle of responsibility and focus for the first time, not just on the economic value that they add, but also on the environmental and social value they add or destroy. They noted that triple bottom line concept captures the essence of sustainability by measuring the impact of organizational activities on the world. This includes both its profitability and shareholder values and its social, human, and environmental. [18], explained that an environmental bottom line is expected to show how the company has contributed to the sustainability of its environment (including the environment of its suppliers, customers, and investors), by minimizing contamination and ensuring a sustainable inventory of natural resources. [19], stated that by implication, if government assumes that business can and will pursue more sustainable options of their own accord, and in accordance with options which are available in market place, then moves towards sustainability will be very slow. [20], argued that many social and environmental phenomena cannot be easily considered numerically. Therefore, the concept of a bottom line for the social and environmental impacts of companies is conceptually flawed, and its lack of clarity has enabled managers to define social and environmental issues in terms of financial viability for the company. He added that issues of human rights, pollution and so forth should not be compromised, and that decisions regarding such compromises should not be left to organizations that seek profit. [21], in their study outlined the benefits of social reporting for organisations, which could also be inferred to its environmental counterpart: (Convergence Claim) Measuring social performance helps improve social performance, and firms with better social performance tend to be more profitable in the long-run; (Strong Social-obligation Claim) Firms have an obligation to maximise (or weaker: to improve) their social bottom line their net positive social impact and accurate measurement is necessary to judge how well they have fulfilled this obligation and (Transparency Claim) The firms have obligations to stakeholders to disclose information about how well it performs with respect to all stakeholders. [17], added that Triple Bottom Line Reporting goes beyond the traditional way of reporting mechanism and encourages businesses to give closer attention to the whole impact of their commercial activities, over and above their financial performance. They added that such reporting tool responds to all stakeholder demands that companies take part in, be accountable for, and substantiate their membership in society. This view was supported by [22], when he opined that a firm is not just a bundle of shares, but a collection of relationships between its owners, managers, employees, customers, suppliers and the society as a whole. Such a reporting mechanism not only overcomes the existing historical cost based accounting principle but also provides a platform so that the company's performance and its impact can be measured and communicated in a more reliable manner. [23], opined that corporate performance is a function of market mechanism reflected in the way the company interacts with the financial, factor and customer product markets. In the financial market, corporate performance strives to satisfy shareholders and creditors in the form of financial indicators. In the factor market, such as suppliers and other production owners, the corporate ability to pay in time and in agreed amount are important in evaluating corporate performance. [24], in their study argued that there exist absurdity behind efforts to account for sustainability at an organizational level when sustainability is primarily a global concept, and where the impacts of one organization matter far less than the cumulative interactions of multiple organizations on carrying capacity of the global ecosystem, not just for the current generation but for all future generations. They concluded that while it may be possible to account for elements of un-sustainability and for contributions detractions from social justice, a full account of sustainability makes no sense at an organizational level. In his own contribution, [25], noted that a company's financial statement are not able to account for the wider 
economic impacts of a company's activities at the local community level through the provision of employment, the income that employees earn and use, and the taxes that they pay, as well as the impact on local suppliers and service providers. He concluded that while the economic component of the triple bottom line is often assumed to be synonymous with financial performance, there are significant differences between the two: in its simplest form, finance is about the provision of money when and where required for consumption or for investment in commerce. As such, it concerns the market valuation of transactions that pass through a company's books. Economics, on the other hand, is the means by which society uses human and natural resources in the pursuit of human welfare. Hence, economics extends beyond the boundaries of a single organization and is inextricably associated to both the environment and social element of sustainable development. [26], argued that the association of triple bottom line with accounting has allowed it to degenerate from a useful heuristic into a simple set of indicators that constitute some kind of decision algorithm mechanism. He added that the push to a language of accounting or economics is likely to ignore many of the truly social issues. In the corporate world, such a danger may not just be about ignoring key social issues but also manipulating their importance with respect to the primary function of making a profit. [27], speaking on organization collaboration on sustainable development noted that some aspects of society are clearly unsustainable but are beyond the scope of one organization to influence even if these aspects are critical to the organization's future or that of its stakeholders. There are clear benefits from organizations working together to find ways to ensure we all operate within the carrying capacity of supporting ecosystems. [28], analyzed the experiences of six European-based companies in terms of the changes that resulted from learning about and incorporating sustainability management processes into their organizations. These companies were divided into those that they defined as having undergone incremental change processes and those that went through radical changes, such as the creation of new structures and procedures. Double loop learning was associated with both types of changes; only one company effected change through single loop learning experiences. They noted that the size of the company and external factors such as market and policy drivers influences the extent of change that results in their study. They also highlighted the key positive role played by change agents in effecting change, noting that in medium-sized companies, change agents were often in managerial positions, whereas in larger companies they were located in the sustainability or research departments. Speaking on determinants of triple bottom line reporting, [29], suggested that corporate liquidity is an important determinant of disclosures in both corporate financial and non-financial information. In particular, they indicated that stakeholders are concerned regarding the status of the company as a going concern, so that those with higher liquidity may have stronger incentives to provide more financial and non-financial information in their annual reports than company's' with lower liquidity. According to [30], it is not sufficient for managers to focus exclusively on the needs of shareholder or the owners of the corporation. Stakeholder theory implies that it can be beneficial for the firm to engage in certain corporate social responsibility activities that non-financial stakeholders perceive to be important; otherwise these groups might withdraw their support. He noted that stakeholder groups vary from firm to firm, as well as the importance of each of them. He suggested that corporate social responsibility should begin with identification of stakeholders and follow by finding the strategy on how to satisfy and harmonize their expectations. Continuous performance is the main purpose of any organization because only through performance can organization be able to grow and progress. The concept of corporate performance of organization is believed to be unclear; this is because scholars often agree that there is no universal definition of the concept. However, scholars often concur that corporate performance is a function of time and organizational context. [23] defined corporate performance as the organization's ability to attain its goals by using resources in an efficient and effective manner. They divide corporate performance into operational and financial performances. Operational performance includes: (i) market share, (ii) product quality, and (iii) marketing effectiveness. Financial performance is broken down into two subcategories: (i) market-based performance (e.g., stock price, dividend payout and earnings per share) and (ii) accounting-based performance (e.g., return on assets and return on equity). In addition, corporate performance is a function of market mechanism reflected in the way the company interacts with the financial, factor and customer product markets. In the financial market, corporate performance strives to satisfy shareholders and creditors in the form of financial indicators. In the factor market, such as suppliers and other production owners, the corporate ability to pay in time and in agreed amount are important in evaluating corporate performance ([23], [17]). Speaking on corporate performance, [31] provide a set of definitions to illustrate the concept of organizational performance:

a. Performance is a set of financial and nonfinancial indicators which offer information on the degree of achievement of objectives and results;

b. Performance is dynamic, requiring judgment and interpretation;

c. Performance may be illustrated by using a causal model that describes how current actions may affect future results;

d. Performance may be understood differently depending on the person involved in the assessment of the organizational performance (e.g. performance can be understood differently from a person within the organization compared to one from outside);

e. To define the concept of performance is necessary to know its elements characteristic to each area of responsibility; and,

f. To report an organization's performance level, it is 
necessary to be able to quantify the results.

The concept of corporate performance in accounting literatures refers normally to financial aspects such as profit, return on assets (ROA) and economic value added (EVA), using the nick name of 'the bottom line' ([23], [17]). Drawn from the perspective of customer product market, corporate performance will be evaluated by parties in the market based on the ability of the corporation to deliver value to customers with affordable price which is the net effect, in turn, will be indicated in the corporate revenue.

\section{Material and Methodology}

\subsection{Data Collection}

The source of data for this study was secondary data obtained from Central Bank of Nigeria Statistical Bulletin 2010 and annual reports 2008-2012 of three selected public limited companies operating in Nigeria.

\subsection{Regression Analysis}

Regression Analysis was used to determine the contributions of the explanatory variable "Corporate Social Responsibility (CSR)" on the dependent variable profit After Tax. Regression analysis explains how one variable is related to another by providing an equation that enables the researcher to estimate the unknown value of a dependent variable using the unknown values of an independent variable [32]. Multiple regression analysis is a statistical technique that can be used to analyze the relationship between a single dependent (criterion) variable and several independent (predictor) variables [33].

The regression test statistic linear model parameters is given by

$$
y=\beta_{0}+\beta_{1} x_{1}+\beta_{2} x_{2}+\cdots+\beta_{n} x_{n}+\varepsilon_{n}
$$

The matrix form of equation (1) is expressed as

$$
\begin{gathered}
y=X \beta+\varepsilon \\
\hat{\beta}=\left(X^{\prime} X\right)^{-1} X^{\prime} y
\end{gathered}
$$

Where the y represents the dependent variable for the present study which is Profit After Tax (PAT) and the explanatory or independent variable parameter $\left(\beta_{1}\right)$, represents the coefficient of the variable Corporate Social Responsibility (CSR).Also, $\beta_{0}$ represents the parameter of the regression model constant and $\mathcal{E}$ represents the error or random effect of the model. The test of hypothesis for the present study is stated as given;

$\mathrm{H}_{0}$ : There is no significant contribution of Corporate Social Responsibility (CSR) on Profit after Tax (PAT).

$\mathrm{H}_{1}$ : There is significant contribution of Corporate Social Responsibility (CSR) on Profit after Tax (PAT).

Decision Rule: The decision rule is reject the null hypothesis when the P-value is less or equal to the $\alpha=0.05$, otherwise, accept the null hypothesis.

\section{Analysis and Result}

\subsection{Regression on Financial Performance of OANDO GROUP Nig. Plc}

Table 1. Model Summary

\begin{tabular}{lllll}
\hline Model & R & R Square & $\begin{array}{l}\text { Adjusted } \\
\text { Square }\end{array}$ & $\begin{array}{l}\text { Std. Error of } \\
\text { the Estimate }\end{array}$ \\
\hline 1 & $.980^{\mathrm{a}}$ & .961 & .948 & $9.07299 \mathrm{E} 8$ \\
\hline
\end{tabular}

a. Predictors: (Constant), CSR(OANDO GROUP)

Table 2. $A N O V A^{b}$

\begin{tabular}{lllllll}
\hline \multicolumn{2}{l}{ Model } & $\begin{array}{l}\text { Sum of } \\
\text { Squares }\end{array}$ & df & $\begin{array}{l}\text { Mean } \\
\text { Square }\end{array}$ & F & Sig. \\
\hline & Regression & $6.125 \mathrm{E} 19$ & 1 & $6.125 \mathrm{E} 19$ & 74.402 & $.003^{\mathrm{a}}$ \\
1 & Residual & $2.470 \mathrm{E} 18$ & 3 & $8.232 \mathrm{E} 17$ & & \\
& Total & $6.372 \mathrm{E} 19$ & 4 & & & \\
\hline
\end{tabular}

a. Predictors: (Constant), CSR(OANDO GROUP)

\begin{tabular}{|c|c|c|c|c|c|c|}
\hline \multirow{2}{*}{\multicolumn{2}{|c|}{ Model }} & \multicolumn{2}{|c|}{$\begin{array}{l}\text { Unstandardized } \\
\text { Coefficients }\end{array}$} & \multirow{2}{*}{$\begin{array}{l}\text { Standardized } \\
\text { Coefficients } \\
\text { Beta }\end{array}$} & \multirow[t]{2}{*}{$\mathbf{t}$} & \multirow[t]{2}{*}{ Sig. } \\
\hline & & B & Std. Error & & & \\
\hline \multirow[b]{2}{*}{1} & (Constant) & $1.697 \mathrm{E} 10$ & $9.663 \mathrm{E} 8$ & & 17.566 & .000 \\
\hline & $\begin{array}{l}\text { CSR(OANDO } \\
\text { GROUP) }\end{array}$ & -37.228 & 4.316 & -.980 & -8.626 & .003 \\
\hline
\end{tabular}

b. Dependent Variable: PAT(OANDO GROUP)

Table 3. Coefficients ${ }^{a}$

a. Dependent Variable: PAT(OANDO GROUP)

\subsection{Regression on Financial performance of TOTAL Nig. Plc}

Table 4. Model Summary

\begin{tabular}{lllll}
\hline Model & R & R Square & $\begin{array}{l}\text { Adjusted R } \\
\text { Square }\end{array}$ & $\begin{array}{l}\text { Std. Error of } \\
\text { the Estimate }\end{array}$ \\
\hline 1 & $.309^{\mathrm{a}}$ & .095 & -.206 & $3.91023 \mathrm{E} 8$ \\
\hline
\end{tabular}

a. Predictors: (Constant), CSR(Total NiG PLC)

Table 5. $A N O V A^{b}$

\begin{tabular}{lllllll}
\hline \multicolumn{2}{l}{ Model } & $\begin{array}{l}\text { Sum of } \\
\text { Squares }\end{array}$ & df & $\begin{array}{l}\text { Mean } \\
\text { Square }\end{array}$ & F & Sig. \\
\hline & Regression & $4.841 \mathrm{E} 16$ & 1 & $4.841 \mathrm{E} 16$ & .317 & $.613^{\mathrm{a}}$ \\
1 & Residual & $4.587 \mathrm{E} 17$ & 3 & $1.529 \mathrm{E} 17$ & & \\
& Total & $5.071 \mathrm{E} 17$ & 4 & & & \\
\hline
\end{tabular}

a. Predictors: (Constant), CSR(Total NiG PLC)X2

b. Dependent Variable: PAT(Total NiG PLC) 
Table 6. Coefficients ${ }^{a}$

\begin{tabular}{|c|c|c|c|c|c|c|}
\hline \multirow{2}{*}{\multicolumn{2}{|c|}{ Model }} & \multicolumn{2}{|c|}{$\begin{array}{l}\text { Unstandardized } \\
\text { Coefficients }\end{array}$} & \multirow{2}{*}{$\begin{array}{l}\text { Standardized } \\
\text { Coefficients } \\
\text { Beta }\end{array}$} & \multirow[t]{2}{*}{$\mathbf{t}$} & \multirow[t]{2}{*}{ Sig. } \\
\hline & & B & Std. Error & & & \\
\hline \multirow[b]{2}{*}{1} & (Constant) & 4.720E10 & $7.648 \mathrm{E} 10$ & & .617 & .581 \\
\hline & $\begin{array}{l}\text { CSR(Total } \\
\text { NiG PLC) }\end{array}$ & -10745.897 & 19097.045 & -.309 & -.563 & .613 \\
\hline
\end{tabular}

a. Dependent Variable: PAT(Total NiG PLC)

\subsection{Regression on Financial Performance of Guiness Nig. Plc}

Table 7. Model Summary

\begin{tabular}{lllll}
\hline Model & R & R Square & $\begin{array}{l}\text { Adjusted R } \\
\text { Square }\end{array}$ & $\begin{array}{l}\text { Std. Error of } \\
\text { the Estimate }\end{array}$ \\
\hline 1 & $.462^{\mathrm{a}}$ & .214 & -.048 & $2.29686 \mathrm{E} 9$ \\
\hline
\end{tabular}

a. Predictors: (Constant), CSR(Guiness NIG PLC)

Table 8. $A N O V A^{b}$

\begin{tabular}{lllllll}
\hline \multicolumn{2}{l}{ Model } & $\begin{array}{l}\text { Sum of } \\
\text { Squares }\end{array}$ & df & $\begin{array}{l}\text { Mean } \\
\text { Square }\end{array}$ & F & Sig. \\
\hline & Regression & $4.304 \mathrm{E} 18$ & 1 & $4.304 \mathrm{E} 18$ & .816 & $.433^{\mathrm{a}}$ \\
1 & Residual & $1.583 \mathrm{E} 19$ & 3 & $5.276 \mathrm{E} 18$ & & \\
& Total & $2.013 \mathrm{E} 19$ & 4 & & & \\
\hline
\end{tabular}

a. Predictors: (Constant), CSR(Guiness NIG PLC)

b. Dependent Variable: PAT(Guiness NIG PLC)

Table 9. Coefficients ${ }^{a}$

\begin{tabular}{|c|c|c|c|c|c|c|}
\hline \multirow{2}{*}{\multicolumn{2}{|c|}{ Model }} & \multicolumn{2}{|c|}{$\begin{array}{l}\text { Unstandardized } \\
\text { Coefficients }\end{array}$} & \multirow{2}{*}{$\begin{array}{l}\text { Standardized } \\
\text { Coefficients } \\
\text { Beta }\end{array}$} & \multirow[t]{2}{*}{$\mathbf{t}$} & \multirow[t]{2}{*}{ Sig. } \\
\hline & & B & $\begin{array}{l}\text { Std. } \\
\text { Error }\end{array}$ & & & \\
\hline \multirow[b]{2}{*}{1} & (Constant) & $1.651 \mathrm{E} 10$ & $2.601 \mathrm{E} 9$ & & 6.346 & .008 \\
\hline & $\begin{array}{l}\text { CSR(GuinessNiG } \\
\text { PLC) }\end{array}$ & -19.395 & 21.471 & -.462 & -.903 & .433 \\
\hline
\end{tabular}

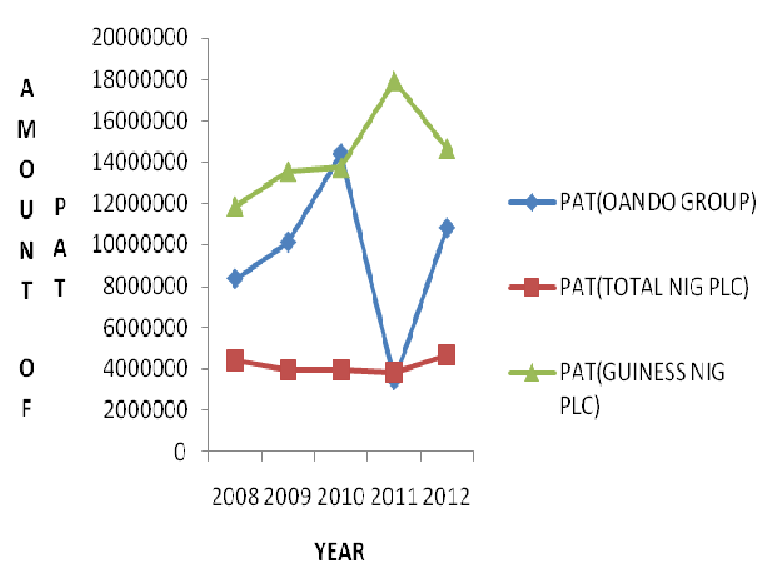

Figure 1. Graphical representation of profit after tax for the three companies from the year 2008-2012.

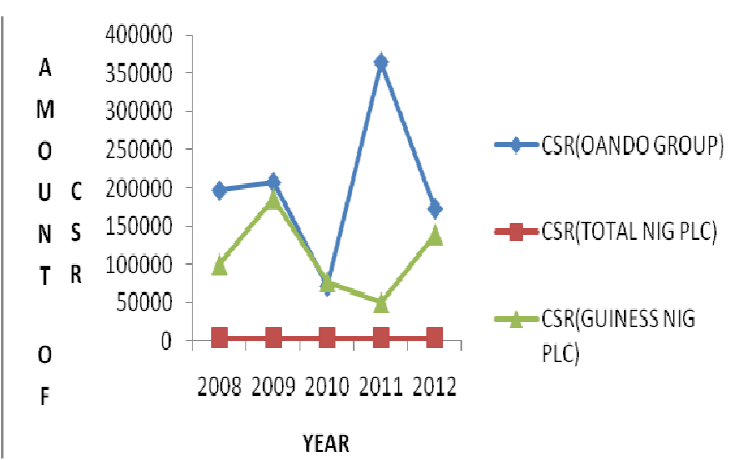

Figure 2. Graphical representation of corporate social responsibility for the three companies from the year 2008-2012.

\section{Discussion}

The result of the analysis presented in Table 1 showed that corporate social responsibility (CSR) was able to explain about $96.1 \%$ of the behavior of profit after tax in OANDO Group Nig. Plc, since the coefficient of determination (R-sqaure) was obtained as 0.961 . Table 2 showed that the predictor (Independent variable) contributed significantly to the model with an F-ratio measure of 74.402 and a p-value of 0.003 which falls on the rejection region of the hypothesis. Also, Table 3 expressed that as profit after tax is increasing corporate social responsibility is decreasing by 37.23 coefficients.

The result of the analysis displayed in Table 4 showed that the corporate social responsibility (CSR) was able to explain about $9.5 \%$ of the behavior of profit after tax in Total Nig. $\mathrm{Plc}$, since the coefficient of determination (R-sqaure) was obtained as 0.095 . Table 5 showed that the predictor (Independent variable) did not contributed significantly in the model with an F-ratio measure of 0.317 and a p-value of 0.613 which falls on the acceptance region of the hypothesis. Also, Table 6 showed that as profit after tax is increasing corporate social responsibility is decreasing by 10745.89 coefficients.

Furthermore, the result of the analysis presented in Table 7 showed that corporate social responsibility (CSR) was able to explain about $21.4 \%$ of the behavior of profit after tax in Guiness Nig. Plc, since the coefficient of determination (R-sqaure) was obtained as 0.214 . Table 8 showed that the predictor (Independent variable) did not contributed significantly in the model with an F-ratio measure of 0.816 and a p-value of 0.433 which falls on the acceptance region of the hypothesis. Also, Table 9, showed that as profit after tax is increasing corporate social responsibility is decreasing by 19.39 coefficients.

From the graphical expression in Figure 1, it can be seen that Guniess Nig. Plc, recorded the largest profit after tax over the observed period followed by OANDO Group Nig. Plc. Also, from Figure 2, it was observed that OANDO Group Nig. Plc, recorded the largest value in terms of corporate social responsibility, followed by Guiness Nig. Plc, over the observed period. 


\section{Conclusion}

This study was on determining the contribution of corporate social responsibility on organizational performance. From the result of the analysis it was found that corporate social responsibility was able to explain and contribute significantly to company's performance more in OANDO Group Nig. Plc. This result implies that OANDO Group Nig. Plc was observed to spend more in terms of corporate social responsibility amongst the observed company's and in turn corporate social responsibility contributing to its performance. Also, it was found that Guniess Nig. Plc recorded the largest profit after tax over the observed period followed by OANDO Group Nig. Plc. It can be generalized that sustainability reports does have an association with company performance. Social performance disclosure has an association with company's performance as was found by the result of OANDO Group Nig. Plc. For companies, improving sustainability performance is important. Even it is as important as improving company's financial performance. Sustainability means the development that meets the needs of the present without compromising the ability of future generations to meet their own needs. It implies that, in running the business, a company need to concern to the needs of future generations [1]. Though reporting on its environmental performance may expose a company to criticisms and also have minimal effect in the short run. It is advisable that the company continues to disclose its environmental performance because in the long run it would help in achieving sustainability [34].

\section{References}

[1] Annisa Hayatun N. Burhan, Wiwin Rahmanti. (2012). The Impact of Sustainability Reporting on Company Performance. Journal of Economics, Business, and Accountancy Ventura, 15(2), pages $257-272$.

[2] Choi, Frederick DS and Gary K Meek. (2008). International Accounting. 6th Edition, New Jersey: Pearson Prentice Hall.

[3] Mitchell, M., Curtis, A., and Davidson, P. (2008). Evaluating the process of triple bottom line reporting: increasing the potential for change. Local Environment, 13(2): 67-80.

[4] Hubbard, Graham. (2008). December 15, Beyond Accounting-Assessing the Impact of Sustainability Reporting on Tomorrow's Business. A Discussion Paper, Adelaide, Australia.

[5] McEntyre, R. (2003). Triple Bottom Line and the Community Library. Retrieved November 21, 2012 from www.mcentyre.com.au/articles/triple_bottom_line.pdf

[6] Chapman, R., \& Milne, M. J. (2004). The Triple Bottom Line: How New Zealand Companies Measure Up. Corporate Environmental Strategy: International Journal for Sustainable Business, 11(2), 37-50.

[7] Dutta, S. et.al. (2011). Triple Bottom Line Reporting: an innovative accounting initiative. International Journal on Business, Strategy and Management, 1(1), 1-13.
[8] Aras, Guler and David Crowther. (2009). Corporate Sustainability Reporting: A Study in Disgenuity. Journal of Business Ethics, 87: 279-288.

[9] Ngwakwe, Collins, C. (2008). Environmental Responsibility and Firm Performance: Evidence from Nigeria. Proceeding of World Academy of Science, Engineering, and Technology, 36.

[10] Casanova, L. (2010). Corporate Social Responsibility and Latin American Multinationals: Is Poverty a Business Issue? Universia Business Review, 132-145. Retrieved from ubr.universia.net/pdfs_web/25010-07.pdf

[11] Lopez, M Victoria, Arminda Garcia, and Lazaro Rodriguez. (2007). Sustainable Development and Corporate Performance: A Study Based on the Dow Jones Sustainability Index. Journal of Business Ethics, 7; 285-300.

[12] KPMG. (2008). Sustainability Reporting: A Guide. Australia

[13] Basamalah, Anies. S and Johnny Jermias. (2005). Social and Environmental Reporting and Auditing in Indonesia: Maintaining Organizational Legitimacy?, Gadjah Mada International Journal of Business, 7(1): 109-127.

[14] Sitepu, Surya Syahputra. (2009). Pengaruh Pengungkapan Tanggung Jawab Sosial terhadap Kinerja Perusahaan, Skripsi S1, Universitas Gadjah Mada.

[15] Nakamura, Eri. (2011). Does Environmental Investment Really Contribute to Firm Performance? An Empirical Analysis Using Japanese Firms', Eurasian Business Review, 1(2), pp. 91-111.

[16] Gray, R. (2002). THE Social Accounting Project and Accounting Organizations and Society-Privileging Engagements Imaginings, new Accountings and Pragmatism over Critique? Accounting, Organizations and Society, 27(7): 687-708.

[17] Ekwueme, C. M., Egbunike, C. F. \& Onyali, C. I. (2013). Benefits of Triple Bottom Line Disclosures on Corporate Performance: An Exploratory Study of Corporate Stakeholders. Journal of Management and Sustainability; Vol. 3, No. 2: 79-91.

[18] Cheney, H., Nheu, N., and Vecellio, L. (2004). Sustainability as social change: values and power in sustainability discourse. In proceedings of the sustainability and social science: Round table Proceedings, Melbourne.

[19] Bebbington, J. And Gray, R. (2001). An account of sustainability: failure, success and a reconceptualization. Critical Perspectives on Accounting, 12(5): 557-588.

[20] Bendell, J., and Keanrins, K. (2005). The political bottom line: The emerging dimension to corporate responsibility for sustainable development. Business Strategy and the Environment, 14(6): 372-383.

[21] Norman, W., \& MacDonald, C. (2004). Getting to the bottom of the "triple bottom line". Business Ethics Quarterly, 14(2), 243-262. http://dx.doi.org/10.5840/beq200414211

[22] Osisioma, B. C. (2010). Global Financial Crisis: Impact on the Changing Face of Accountancy Profession. Frontier Lecture Series 001, Department of Accountancy: Nnamdi Azikiwe University. 
[23] Fauzi, H., Svensson, G., \& Rahman, A. (2010). Triple Bottom Line" as "Sustainable Corporate Performance": AProposition for the Future. Sustainability, 2(5), 1345-1360. http://dx.doi.org/10.3390/su2051345

[24] Gray, R., and Milne, M. (2004). Reporting on the Triple Bottom Line: Mirages, methods and Myths. In A. Henriques \& J. Richardson (Eds), The triple bottom line, does it all add up? Assessing the sustainability of business and CSR (pp. 70-80). London: Earthscan.

[25] Jennings, V. (2004). Addressing the Economic Bottom Line. In A. Henriques \& J. Richardson (Eds), The triple bottom line, does it all add up? Assessing the sustainability of business and CSR (pp. 155-166). London: Earthscan.

[26] Vanclay, F. (2003). Experiences from the field of social impact assessment: Where do TBL, EIA and SIA fit in relation to each other? In B. Pritchard, A. Curtis, J. Spriggs \& R. Le Heron (Eds), Social dimensions of the triple bottom line in rural Australia (pp. 61-80). Canberra: Bureau of Rural Sciences.

[27] Veleva, V., Hart, M., Greiner, T., and Crumbley, C. (2003). Indicators for Measuring Sustainability: A case study of the pharmaceutical Industry. Benchmarking: An International Journal, 10(2): 107-119.

[28] Siebenbuner, B., and Arnold, M. (2007). Organizational learning to manage sustainable development. Business Strategy and the Environment, 16(5): 339-353.
[29] Ho, L. C. J., \& Taylor, M. E. (2007). An Empirical Analysis of Triple Bottom-line Reporting and its Determinants: Evidence from the United States and Japan. Journal of International Financial Management and Accounting, 18(2), 123-150.

http://dx.doi.org/10.1111/j.1467-646X.2007.01010.x

[30] Freeman, R. E. (1984) Strategic Management, A Stakeholder Approach, Pitman Publishing Inc, Massachusetts.

[31] Gavrea, C., Ilies, L., and Stegerean, R. (2011). Determinants of organizational performance: The case of Romania. Management \& Marketing, 6(2), 285-300.

[32] Draper, N. R. and H. Smith. (1981). Applied Regression Analysis. $2^{\text {nd }}$ ed. John Wiley, New York.

[33] Motulsky, H.J and A. Christopoulos. (2003), Fitting models to Biological Data using Linear and Nonlinear Regression. A practical guide to curve fitting. Graphpad Software Inc., San Diego CA,.

[34] Mitchell, M., Curtis, A, and Davidson, P. (2007). Can the "triple bottom line" concept help organisations respond to sustainability issues? In proceedings of the $5^{\text {th }}$ Australian Rivers: Making a difference, Charles Sturt University Institute for Land, Water and Society, Albury, NSW, 21-25 May 2007: pp. 270-275. Available from http://www.Csu.edu.au/research/ilws/news/events $/ 5 \mathrm{a} 3 \mathrm{~m} /$ pro ceedings 